\title{
Supply Chain Financing Models Based on Internet Finance
}

\author{
Haibin Xu \\ 6F, Building B, No.1289 Yishan Road, Shanghai P.R.China \\ 13917229508@139.com
}

Keywords: Supply chain finance; Internet finance; Bank; Logistics; Core enterprise; Big data

\begin{abstract}
In March 2015, the 12th session of the National People's Congress, the third session of the opening of the conference, Premier Li Keqiang proposed the "Internet +" plan. After that, Internet financial became a hot issue nowadays. On the other hand, because of traditional bank credit set a relative strict prerequisite for Small and Medium Enterprises (SMEs), supply chain finance, which ties up the core enterprise with upstream and downstream SMEs by providing financial service, cut down SMEs' financing cost. For enterprises, which improve upstream and downstream SMEs by effectively integrating goods flows, information flows and financial flows benefit a lot from it. Based on the trend of the Internet finance, combined with the experience of traditional supply chain development, the research object of this article is the supply chain finance model based on Internet finance. This paper sums up to three models, such as commercial bank model, On-line platform mode, and core enterprise model. Finally, this paper points out the significance of supply chain finance combined with Internet to SMEs in China.
\end{abstract}

\section{Introduction}

Since 2014, the Internet finance has become the focus of China's "Internet +" era. The Internet finance is the symbol of modern economy entered the era of Internet. The Internet financial represents new technologies, new models and new features.

Through Internet finance, the marketization of finance can be promoted, the efficiency of capital allocation is improved, as well as the quality of financial service. The innovation of financial products eases the problem of the finance of SMEs. Although the supply chain finance in our country only ten years, but the development of information technology created the conditions for the supply chain finance combined with the Internet.

With the development of the Internet technology, information technology, big data, and other technical support, the combination of the Internet and the supply chain finance will be able to create a new risk management technology. Concerned about the Internet supply chain finance model and its development trend in the future, so that the supply chain finance can penetrate the logistics flow, information flow and capital flow, followed by the entire industry chain and business direction.

\section{The Model of Internet Supply Chain Finance}

The traditional model of supply chain finance is traditional bank model. The model based on the core enterprise, depended on the real trade background, and viewed self-liquidation trade finance as the premise. Commercial banks through the pledge of accounts receivable, or pledge of goods, or other means to close the flow of funds, from its upstream or downstream enterprises [1]. In this way, commercial banks can provide financing services by controllable risk.

In the "Internet +" era, the supply chain finance entered the stage of the Internet finance. In this way, traditional supply chain finance combined with internet technology. And the supply chain finance can closer ties from the logistics flow, information flow and capital flow [2]. Finally, this kind of financial products services can be realized online.

In the future, with the increasingly participation of the Internet technology, big Internet companies can be one important provider of supply chain finance by its big data. Through the use of big data, we can find the credit in the industry chain [3]. It changes the traditional mode, which need credit increase 
bundled by core enterprise or logistics and warehousing enterprises. And it realizes SMEs obtaining loan without guarantee measures. Such internet companies gradually become an integrated supply chain service platform, which provide credit support for SMEs, and provide a better integrated solution for the core enterprise and the entire supply chain.

Commercial Banks Mode. From the view of traditional commercial banks, the default risk of supply chain finance is higher than mortgage loan or guaranteed loan, so products designed on supply chain are not as popular as traditional financing products.

In the "Internet +" era, commercial banks take advantage of its low cost of capital, firmly grasp the upstream and downstream of the supply chain. With the continuous deepening applications of the Internet technology and big data, commercial banks can design supply chain financial services more suitable and further promote the effective development of business and corporate finance activities. They add the Internet to the traditional business, and launched " $1+\mathrm{N}$ " supply chain finance products online. Through new kind of commercial banks mode, SMEs can be serviced more efficiently.

For example, Ping a Bank, formerly Shenzhen Development Bank, has been in the field of supply chain finance for more than and 10 years. It establish the classic model of trade financing "Goods + Notes" in 2001, and create "supply chain finance" brand in 2006. Then the 2014, it launches the financial supply chain service platform "Orange E" [4]network, which build a supply chain service platform by coalesce logistics, information flow and capital flow in " three-in-one " [5].

Although Ping and Bank's on-line product "Orange E"'is an internet financial products, but from its business logic, the core concept is supply chain finance. Through Internet technology, the business and products of supply chain finance become more active, development collaboratively, which can bring more benefits for the enterprises on supply chain.

On-line Platform Mode. The platform, which essentially has the industry chain of trade information, includes logistics information, capital flow and other relevant data, through the control of logistics and warehousing to close the entire transaction loop.

In this way, standardized financial assets available for trading can be designed to docking capital channel. On-line platform can get core enterprise support to meet the financing needs of the upstream and downstream.

This requirement of model on-line platform is very high, so that the platform which can meet these requirements is behind the Internet industry giants, such as Jingdong Finance. Supply chain finance is the first service of Jingdong Finance.

Now "Jingbaobei" [6] and "Jingxiaodai" [7] are the two featured products of Jingdong Finance. "Jingbaobei" is mainly designed for the Jingdong's suppliers by providing order financing, accounts receivable financing, chattel financing. According to the requirements of the supplier, it can support different types of financing needs as single financing or dynamic pool financing. Moreover, "Jingxiaodai" is a loan product for the Jingdong's merchant. Borrowers need to be a merchant on Jingdong, and Jingdong Finance give a differentiated loan volume for the borrower, by settled in the orders, transactions, settlement and other integrated business conditions. Borrowers can choose different loan period and repayment according to their own financing needs [8].

The two supply chain finance products, "Jingbaobei" and "Jingxiaodai", are designed by on-line platform mode, which grasp logistics, information flow and capital flow data, can reduce the information asymmetry, so as to reduce the default risk of the financing of the borrower. This pattern has certain significance for other internet companies engaged in the supply chain to reference [9].

Core Enterprise Model. In the new wave of the Internet, much Chinese traditional enterprises have access to the Internet finance. Supply chain finance has become the first choice for many large-scale conglomerates. They have deep industry background, business resources, and absolute control on the upstream and downstream. It's ripe for these core enterprises to develop supply chain finance by using of their own advantages [10].

Haier, for example, its supply chain financial platform "Hairongyi" focuses on supply chain finance of white household appliance. As a leading enterprise in multinational manufacturing, Haier's biggest advantage is the long-term accumulation of traditional industries. Hairongyi participate in the Haier's 
industrial chain as a starting point. The SMEs on the Haier industry chain are generally difficult to obtain bank loans. The actual finance cost they bear is very expensive. However, Haier has detailed historical data of these suppliers and vendors in its ERP system. It makes Hairongyi easy to achieve the risk control on industrial, which is difficult to other platforms.

Relying on Haier, Hairongyi meet different financial needs of supply chain enterprises by using loans, factoring, financial leasing, Internet finance and other financial instruments comprehensively. Hairongyi has achieved good results after less than two years' launch, and achieved exceeded 12 billion turnover by the end of June 2016. The transaction and user registration statistics of Hairongyi can view from table 1 and Fig. 1 below [11].

Table 12016 Jan- Jun transaction and user registration statistics of Hairongyi

\begin{tabular}{|c|c|c|c|c|}
\hline Date & $\begin{array}{c}\text { Accumulative } \\
\text { Volume }\end{array}$ & $\begin{array}{c}\text { Accumulative } \\
\text { Enrollment }\end{array}$ & $\begin{array}{c}\text { Growth Rate of } \\
\text { Accumulative Volume }\end{array}$ & $\begin{array}{c}\text { Growth Rate of } \\
\text { Accumulative Enrollment }\end{array}$ \\
\hline Jan-16 & 58.97 & 174.56 & $19 \%$ & $4 \%$ \\
\hline Feb-16 & 70.03 & 181.69 & $18 \%$ & $4 \%$ \\
\hline Mar-16 & 82.59 & 189.38 & $17 \%$ & $4 \%$ \\
\hline Apr-16 & 96.46 & 196.58 & $15 \%$ & $3 \%$ \\
\hline May-16 & 110.61 & 202.87 & $11 \%$ & $3 \%$ \\
\hline Jun-16 & 122.94 & 208.68 & & \\
\hline
\end{tabular}

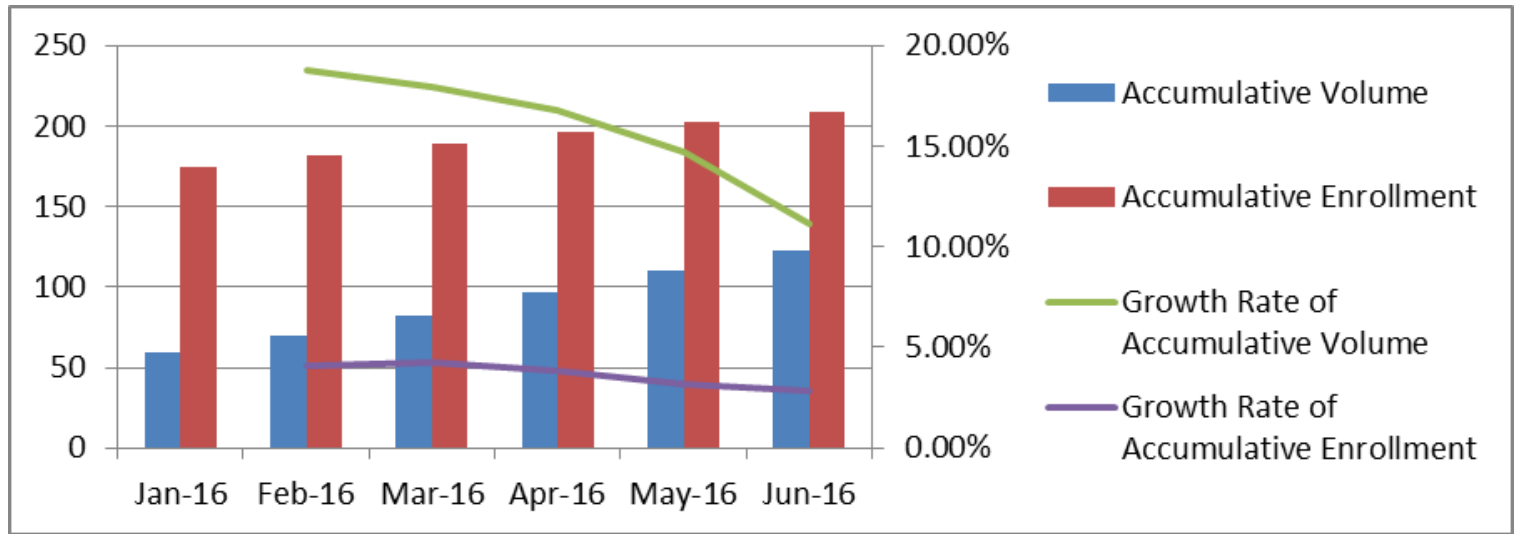

Figure 1. 2016 Jan- Jun transaction and user registration statistics of Hairongyi

Through Hairongyi, Haier open up a new way on transformation and upgrading of traditional enterprise. It is regarded as the paragon of China's manufacturing industry transformation and upgrading of traditional enterprises. Supply chain finance market is broad in China, especially the intervention of traditional enterprises. It will bring huge demand to the real economy.

\section{The Significance of the Internet Supply Chain Finance}

Supply chain finance is a means of financing by credit for enterprises in the industrial chain. However, traditional financial financing mainly depends on mortgages, guarantees and other measures to increase trust. So the two financing ways are distinct.

Although the supply chain finance has been carried out in the United States for many years, but with the development of Internet technology, the development of supply chain finance in China will be entirely different.

Ease the Financing Difficulties of SMEs. Under the traditional bank credit model, the default cost of SMEs is high, which is the important factors of SMEs financing problem.

The risk management of supply chain financing models based on internet finance, is established on strong control of the core enterprise upstream and downstream, with large data support to further enhance the risk pricing capabilities, with support of large data, the risk pricing capabilities is further enhanced. There is stable business relationship between core enterprise and borrowers, it can establish 
mutually beneficial mechanism more effectively, which will reduce the default and increase the repayment [12].

Promote Deep Integration of Industry and Financing. In China, due to the financial regulatory constraints, there are still many difficulties for financial institutions to participate in industrial investment.

At present, large enterprise groups in China often combine industrial capital and financial by establishment of financial companies, factoring companies, or jointing stock in financial institutions. Supply chain finance expand the way of combining industry and financial. In the promotion of internet technology, this kind of combination reducing the transaction costs between enterprises. With the new combining of industry and finance, the core enterprises will enhance the coordination of the entire industrial chain, and the value of the industrial chain will increase.

Accelerate the Reform of China's Financial System. The supply chain has the characteristics of steady development. It greatly speeding up the process of financial disintermediation from commercial credit into market credit and financial resources can penetrate the real economy.

With a large number of private enterprises participating in the supply chain, as a financial tool, the internet supply chain finance will be used more and more widely. This is a certain challenge to the traditional financial institutions.

\section{Conclusion}

There is only ten years' history of the supply chain finance in our country, but the information technology and the Internet have created the conditions to the development of the supply chain finance.

With the development of Internet, information technology, and technical support from big data, cloud collaboration, the combination of supply chain finance and internet can create new risk control technology, which can penetrate the financial supply chain logistics, information flow and capital flow. The supply chain financing models based on internet finance will be followed by the whole industry chain and business direction more closely.

\section{Acknowledgements}

My deepest gratitude goes to Professor Shifeng Wang, my supervisor, for his constant encouragement and guidance. He has walked me through all the stages of the writing of this thesis. I hereby extend my grateful thanks to him for his kind help, without him the paper would not have been what it is.

\section{References}

[1] P. Xie and C.P. Zou: Internet financial model research, J. Finance Research, 12 (2012) 11-22. (In Chinese)

[2] T.J. Jiang: The research of Internet financial model, J. Business, 42(2015) 168-168. (In Chinese)

[3] Huang R, Chen T and Huang: A Comparative Study of the Internet Supply Chain Finance Model. J. Journal of Guangdong University of Foreign Studies, 2016.

[4] Information on http://www.chengyi.cn/

[5] D.Wu: The bonafide of "Orange E”, J. 21st Century Business Review, 13(2014) 52-53. (In Chinese)

[6] Information on https://loan.jd.com/scf/

[7] Information on https://loan.jd.com/home.htm

[8] Y.He, Y.Chen and Y.C. Dai: The Supply Chain Financing Model Analysis of Jingdong,J. Finance and Accounting, 17(2016) 20-22. 
[9] H.M. Li: The analysis on financial risk and countermeasure of Jingdong supply chain, J. E-commerce, 2015(10) 60-61.

[10] H.J. Yan, X.T. Xu: The Analysis of Supply Chain Finance SMEs Financing Model, J. Shanghai Finance, 2(2007) 14-16. (In Chinese)

[11] Information on https://www.hairongyi.com/operationdata

[12] J.C. Cai: The Development Trend of the Internet Financial Supply Chainj, J. China Logistics \& Purchasing, 2014(22) 62-62. 